\title{
ШЛЯХИ КОРЕКЦІЇ ОСТЕОДЕФІЦИТУ ПРИ ХРОНІЧНОМУ ПАНКРЕАТИТІ
}

\author{
ОІ. В. Семенова, Л. С. Бабінець, Ю. Я. Коцаба, О. І. Криськів, О. Б. Велика, Т. А. Заєць
}

ДВНЗ «Тернопільський державний медичний університет імені І. Я. Горбачевського мОЗ України»

РЕЗЮМЕ. Актуальність проблеми розвитку остеодефіцитних станів при хронічному панкреатиті зумовлена розладами процесів травлення, що виявляється синдромами мальдигестії та мальабсорбції з порушенням засвоєння мінеральних і органічних речовин. Ключовим моментом у розвитку остеодефіциту при хронічному панкреатиті, безумовно, $\epsilon$ дефіцит кальцію та вітаміну $\mathrm{D}_{3}$. Остеодефіцит при ХП може мати компоненти як остеомаляції (внаслідок гіповітамінозу вітаміну $\mathrm{D}_{3}$ ), так і остеопорозу (порушення кальцієво-фосфорного, білкового обмінів вторинно, а також внаслідок первинного остеопорозу - вікового, постменопаузального). 3 метою оцінки стану мінеральної щільності кісткової тканини хворим проводили обстеження поперекового відділу хребта за допомогою двофотонного рентгенівського денситометра. Встановлено, що у 75 \% обстежених хворих на хронічний панкреатит спостерігаються порушення мінералізації кісткової тканини.

Проведені дослідження обґрунтовують доцільність спільного використання кальцієвмісного вітамінномінерального препарату та бісфосфонату ризендронової кислоти за запропонованою схемою у лікуванні супутнього остеопорозу у хворих на хронічний панкреатит. Доведено доцільність використання препаратів Вітрум Кальціум 600+D400 та Ризендрос в комплексному лікуванні хворих на хронічний панкреатит із супутнім остеодефіцитом, що привело до суттєвого достовірного покращення стану мінералізації кістки - приросту мінеральної щільності кісткової тканини.

КЛЮчОВІ СЛОВА: хронічний панкреатит; остеодефіцит; мінеральна щільність кісткової тканини; мінеральний обмін; Вітрум Кальціум 600+D400; Ризендрос.

Вступ. Хронічний панкреатит (ХП) часто перебігає у коморбідному поєднанні з остеодефіцитом (ОД) і навіть з остеопорозом (ОП), який являє собою системне метаболічне захворювання скелета, що характеризується зниженням кісткової маси в одиниці об'єму, порушенням мікроархітектоніки кістки з підвищенням ризику виникнення переломів. Часто лікарі стикаються з вторинними формами ОП, які розвиваються у пацієнтів з різними нозологіями, що перебігають із порушеннями обмінних процесів, зокрема з хворобами системи травлення, включаючи ХП. Актуальність проблеми розвитку остеодефіцитних станів при ХП зумовлена розладами процесів травлення, що виявляється синдромами мальдигестії та мальабсорбції з порушенням засвоєння мінеральних і органічних речовин. Крім того, такі пацієнти змушені дотримуватися дієти, що призводить до незбалансованості харчування.

Ключовим моментом у розвитку ОП при ХП, безумовно, $\epsilon$ дефіцит кальцію та вітаміну $\mathrm{D}_{3}$. ОД при ХП може мати компоненти як остеомаляції (внаслідок гіповітамінозу вітаміну $\mathrm{D}_{3}$ ), так і OП (порушення кальцієво-фосфорного, білкового обмінів вторинно, а також внаслідок первинного ОП - вікового, постменопаузального). Серед паці$\epsilon$ нтів з ХП нерідкісним явищем $\epsilon$ зловживання алкоголем, що може сприяти розвитку остеопенії. Поглиблення синдрому панкреатичної та інших видів зовнішньосекреторної недостатності підшлункової залози i/або розвиток панкреатогенного цукрового діабету також обумовлюють ризик формування супутнього ОД.
Матеріал та методи дослідження. Об'єКтом дослідження були 124 пацієнти з ХП, які перебували на диспансерному спостереженні в центрі первинної медико-санітарної допомоги м. Тернополя.

Діагноз ХП встановлювали на підставі даних анамнезу, клінічних проявів (наявність больового, диспепсичного синдромів, зовнішньосекреторної недостатності ПЗ, алергічного, астено-вегетативного, ентеропанкреатичного синдромів і синдрому ендокринних порушень), лабораторних даних, результатів ультразвукового дослідження органів черевної порожнини, езофагогастродуоденоскопії. Критерієм виключення була наявність іншої патології, яка 6 могла викликати розвиток ОД.

Серед аналізованих хворих було 72 жінки (58,1\%) і 52 чоловіки (41,9\%). Вік пацієнтів коливався від 18 років до 79 років. Проведений аналіз показав значне переважання хворих на ХП чоловіків у віковій групі до 45 років над жінками в аналогічній групі і протилежну тенденцію в групі хворих, старших 60 років. Пояснити це можна більш ранньою уражуваністю чоловіків ХП і високим рівнем смертності в молодому і середньому віці.

Середній вік хворих становив $(46,83 \pm 0,89)$ років. Хворих працездатного віку (25-60 років) було 84 (68,9\%), тобто вибірка відображала найактивнішу в соціальному плані частку людей. Такий розподіл вказує на більшу поширеність захворювання серед осіб середнього та зрілого віку, на які припадає період максимального розквіту трудової і соціальної активності людини. 
3 метою оцінки стану мінеральної щільності кісткової тканини (МЩКТ) хворим на ХП проводили обстеження поперекового відділу хребта за допомогою двофотонного рентгенівського денситометpa (Dual Energy X-RayAbsorptiometry - DXA) фірми Lunar corp. (Madison, WI) - LunarDPX-A № 2589. Аналіз МЩКТ проводили методом порівняння даних денситометрії досліджених хворих і здорових людей, отриманих при популяційних дослідженнях, статистично достатніх за об'ємом груп, репрезентативних за расою, статтю, віком та ін. Рівні остеопенії визначали за Л. Я. Рожинською.

Встановлено, що у 93 (75 \%) обстежених хворих на ХП були порушення мінералізації КТ. Ці зміни характеризувались зниженням показників МЩКТ і трактувались як диференційована остеопенія та ОП.

Так, остеопенія діагностована в 59 (47,6 \%) хворих, ОП - у 30 (24,2 \%) пацієнтів. Показники МЩКТ, які відповідають нормі, спостерігались у 28 хворих, що становить 22,6 \% усіх хворих на ХП.

Пацієнтів з ХП і супутнім ОД поділили на три групи за програмами корекції. Під час розподілу пацієнтів на групи керувались консенсусом 2005 року, який рекомендує розглядати необхідність призначення бісфосфонатів (БФ) тільки у хворих з низькою кістковою масою (T/Z - критерій (-2)SD).

I група отримувала загальноприйнятий в гастроентерології лікувальний комплекс (ЗЛ) за вимогою, згідно із станом пацієнтів. Він включав нормотрофне харчування (дієта №5п за Певзнером), пантопразол 20 мг 1 р/д, ферментний препарат чистого панкреатину Креон 250003 р/д під час їди, но-шпа форте 80 мг 2 р/д і/або мотиліум 10 мг 3 р/д до їди.

II група (15 хворих) отримувала 3Л комплекс, посилений використанням кальцієвмісного вітамінно-мінерального препарату Вітрум Кальціум $600+D 400$ за наступною лікувальною схемою - по 1 таблетці 2 рази на добу під час або після їди протягом 1 місяця, пізніше - по 1 таблетці 1 раз на добу протягом 2 місяців. Вітрум Кальціум $600+D 400$ - реєстраційне посвідчення MO3 України № UA/1721/01/01 - являє собою комплекс препаратів кальцію (у вигляді кальцію карбонату з раковин устриць) 600 мг та вітаміну $\mathrm{D}_{3}$ (холекальциферолу) 10 мкг (400 МО).

Хворі III групи протягом 3 місяців приймали разом із ЗЛ перорально 1 раз в тиждень за 30 хвилин до їди БФ - препарат ризендронової кислоти (Ризендрос) в дозі 35 мг, а також кальцієвмісний вітамінно-мінеральний препарат (Вітрум Кальціум 600+D400) за наступною лікувальною схемою - по 1 таблетці 2 рази на добу під час або після їди протягом 1 місяця, пізніше - по 1 таблетці 1 раз на добу протягом 2 місяців.
Результати й обговорення. Під впливом 3Л у хворих на ХП із супутнім ОД I групи (вихідні дані відповідали рівню остеопенії ІІ ст.) показники кісткової тканини дещо знизились, хоча зміни були недостовірними $(p>0,05)$.

У пацієнтів II групи (вихідний стан відповідав рівню остеопенії III ст.) було констатовано наявність приросту МЩКТ на $(0,279 \pm 0,020) г / \mathrm{cm}^{2}$ і на $(3,31 \pm 0,47) \%$. Таким чином, використання Вітрум Кальціум 600+D400 за запропонованою схемою через півроку від початку лікування привело до суттєвого достовірного $(p<0,05)$ покращення стану мінералізації кістки. Зазначимо, що рівень загального кальцію в крові у пацієнтів I групи в ході лікування практично не змінився і знаходився в межах норми. Аналогічний показник в II групі перед лікуванням був дещо нижчим стосовно групи контролю $(p<0,05)$, після проведеної корекції достовірно збільшився і знаходився в межах норми. Рівень неорганічного фосфору в обох групах дослідження був в межах норми як до, так і після лікування, хоч необхідно зазначити достовірне збільшення цього показника $(p<0,05)$ В II групі після проведеної корекції. Показник лужної фосфатази як маркера кісткового метаболізму в групах порівняння знаходився в межах норми, хоча необхідно зазначити достовірне зниження цього показника в II групі після лікування стосовно такого на вході $(p<0,05)$. Це свідчить про позитивний баланс кісткового ремоделювання на користь остеоформування після проведеної корекції.

Проведений аналіз отриманих даних свідчить на користь доцільності використання препарату Вітрум Кальціум 600+D400 в комплексному лікуванні хворих на ХП для корекції супутнього ОД, порушень мінерального обміну та їх профілактики.

У пацієнтів III групи було констатовано наявність приросту МЩКТ на $(0,291 \pm 0,051)$ г/см² і показника Т на $(4,72 \pm 0,34) \%$. Отже, використання препаратів Ризендрос та Вітрум Кальціум $600+D 400$ за запропонованими схемами через півроку від початку лікування привело до суттєвого достовірного $(p<0,05)$ покращення стану мінералізації кістки. Це свідчить про позитивний баланс кісткового ремоделювання на користь остеоформування після проведеної корекції.

Проведене порівняльне дослідження продемонструвало високу ефективність терапії ризендронова кислота/кальцій/вітамін D, порівняно 3 терапією кальцій/вітамін D у хворих з ОД, особливо враховуючи гірший вихідний стан КТ у пацієнтів III групи, порівняно з таким у II групі.

Проведений аналіз отриманих даних свідчить на користь доцільності використання препа- 


\section{Огляди літератури, оригінальні дослідження, погляд на проблему, короткі повідомлення} ратів Ризендрос та Вітрум Кальціум 600+D400 в комплексному лікуванні хворих на ХП для корекції супутнього ОП, порушень мінерального обміну та їх профілактики.

Висновки. 1. Проведені дослідження обґрунтовують доцільність спільного використання кальцієвмісного вітамінно-мінерального препарату та бісфосфонату ризендронової кислоти за запропонованою схемою у лікуванні супутнього остеодефіциту у хворих на хронічний панкреатит.

\section{ЛІТЕРАТУРА}

1. Бабінець Л. С. Порушення екскреторної функції підшлункової залози як фактор формування мінеральної недостатності при хронічному панкреатиті / Л. С. Бабінець // Український морфологічний альманах. - 2006. - № 2. - С. 7-9.

2. Бабінець Л. С. Порушення балансу вітамінів і мінералів у хворих на хронічний панкреатит із супутнім остеодефіцитом / Л. С. Бабінець, С. І. Сміян // Проблеми остеології. - 2005-2006. - Т. 8-9, № 4 (1). - С. 83-86.

3. Древаль А. Н. Современный взляд на роль кальция и витамина Д в профилактике и лечении остеопороза / А. Н. Древаль // Український ревматологічний журнал. - 2009. - № 3. - С. 81-85.

\section{REFERENCES}

1. Babinets, L.S. (2006). Porushennia ekskretornoi funktsii pidshlunkovoi zalozy yak faktor formuvannia mineralnoi nedostatnosti pry khronichnomu pankreatyti [Violation excretory pancreatic function as a factor in the formation of mineral deficiency in chronic pancreatitis]. Ukrainskyi morfolohichnyi almanakh - Ukrainian Morphological Almanac, 2, 7-9 [in Ukrainian].

2. Babinets, L.S., \& Smiian, S.I. (2006). Porushennia balansu vitaminiv i mineraliv u khvorykh na khronichnyi pankreatyt iz suputnim osteodefitsytom [Violation of balance of vitamins and minerals in patients with chronic pancreatitis with concomitant osteodefitsytom]. Problemy osteolohii - Problems of Osteology, 8-9, 4 (1), 83-86 [in Ukrainian].

3. Dreval, A.N. (2009). Sovremennyy vzglyad na rol kaltsyya i vitamyna D v profilaktike i lechenii osteoporoza [Modern view on the role of calcium and vitamin D in the prevention and treatment of osteoporosis]. Ukrainskyi revmatolohichnyi zhurnal - Ukrainian Journal of
2. Прийом Ризендрос 35 мг 1 раз на тиждень у комплексі з вітамінно-мінеральним препаратом ефективніший, порівняно з лікуванням вітамінномінеральним препаратом у хворих на ХП з остеодефіцитом, часто на рівні остеопорозу.

3. Препарат Вітрум Кальціум 600+D400 доцільно призначати для профілактики розвитку остеодефіциту у хворих на ХП за наступною лікувальною схемою - по 1 таблетці 2 рази на добу під час або після їди протягом 1 місяця, пізніше по 1 таблетці 1 раз на добу протягом 2 місяців.

4. Малик Н. В. Проблема остеопорозу очима лікаря загальної практики / Н. В. Малик, І. П. Пасічник, І. М. Марченко // Вісник проблем біології та медицини. - 2009. - № 4. - С. 13-17.

5. Палій І. Г. Зовнішньосекреторна недостатність підшлункової залози як предиктор розвитку остеодефіцитних станів: нові можливості у лікуванні / І. Г. Палій, С. П. Колісник // Новости медицины и фармации. Гастроэнтерология. - 2010. - № 323 (тематичний номер).

6. Якушевская О. В. Влияние медикаментозной терапии на костный метаболизм / О. В. Якушевская // Акушерство и гинекология. - 2011. - № 1. - С. 84-88.

Rheumatology, 3, 81-85 [in Russian].

4. Malik, N.V., Pasechnik, I.P., \& Marchenko, I.M. (2009). Problema osteoporozu ochyma likaria zahalnoi praktyky [The problem of osteoporosis eyes GP]. Visnyk problem biolohii ta medytsyny - Journal of Problems of Biology and Medicine, 4, 13-17 [in Ukrainian].

5. Paliy, I.H., \& Kolisnyk, S.P. (2010). Zovnishnosekretorna nedostatnist pidshlunkovoi zalozy yak predyktor rozvytku osteodefitsytnykh staniv: novi mozhlyvosti u likuvanni [Exocrine pancreatic insufficiency as a predictor of osteodefitsytnyh states: new opportunities for treatment]. Novosti meditsyny $i$ farmatsyi. Gastroenterologiya - News of Medicine and Pharmacy. Gastroenterology, 323 [in Ukrainian].

6. Yakushevskaya, O.V. (2011). Vliyanye medikamentoznoy terapii na kostnyi metabolizm [Influence of drug therapy on bone metabolism]. Akusherstvo y ginekologiya - Obstetrics and Gynecology, 1, 84-88 [in Russian]. 


\title{
Огляди літератури, оригінальні дослідження, погляд на проблему, короткі повідомлення
}

\section{ПУТИ КОРРЕКЦИИ ОСТЕОДЕФИЦИТА ПРИ ХРОНИЧЕСКОМ ПАНКРЕАТИТЕ}

\author{
๑И. В. Семенова, Л. С. Бабинец, Ю. Я. Коцаба, О. И. Крыськив, О. Б. Велика, Т. А. Заец
}

ГвУз «Тернопольский государственный медицинский университет имени И. Я. Горбачевского Мз

Украины»

РЕЗЮМЕ. Актуальность проблемы развития остеодефицитних состояний при хроническом панкреатите обусловлена расстройствами процессов пищеварения, синдромами мальдигестии и мальабсорбции с нарушением усвоения минеральных и органических веществ. Ключевым моментом в развитии остеодефицита при хроническом панкреатите, безусловно, является дефицит кальция и витамина $\mathrm{D}_{3}$. Остеодефицит при XП может иметь компоненты как остеомаляции (вследствие гиповитаминоза витамина $\mathrm{D}_{3}$ ), так и остеопороза (нарушения кальциево-фосфорного, белкового обменов вторично, а также вследствие первичного остеопороза - возрастного, постменопаузального). С целью оценки состояния минеральной плотности костной ткани больным проводили обследование поясничного отдела позвоночника с помощью двофотонного рентгеновского денситометра. Установлено, что у 75 \% обследованных больных хроническим панкреатитом наблюдаются нарушения минерализации костной ткани.

Проведенные исследования обосновывают целесообразность совместного использования кальцийсодержащего витаминно-минерального препарата и бисфосфоната - ризендроновой кислоты по предложенной схеме в лечении сопутствующего остеопороза у больных хроническим панкреатитом. Доказана целесообразность использования препаратов Витрум Кальциум 600+D400 и Ризендрос в комплексном лечении больных хроническим панкреатитом с сопутствующим остеодефицитом, что привело к существенному достоверному улучшению состояния минерализации кости - приросту минеральной плотности костной ткани.

КЛЮЧЕВЫЕ СЛОВА: Хронический панкреатит, остеодефицит, минеральная плотность костной ткани, минеральный обмен, Витрум Кальциум 600+D400, Ризендрос.

\section{WAYS OF OSTEODEFICIENCY CORRECTION AT CHRONIC PANCREATITIS}

\author{
@I. V. Semenova, L. S. Babinets, Yu. Ya. Kotsaba, O. I. Kryskiv, O. B. Velyka, T. A. Zayec \\ I. Horbachevsky Ternopil State Medical University
}

SUMMARY. Background osteodeficiency states at chronic pancreatitis is caused by disorders of digestion that appears malabsorbtion and maldigestion syndromes and in violation of assimilation of mineral and organic matter. A key point in the development osteodeficiency in chronic pancreatitis is certainly a deficiency of calcium and vitamin D3. Osteodeficiency in CP components can be as osteomalacia (vitamin deficiencies due to vitamin D3), and osteoporosis (violation of calcium-phosphorus, protein metabolism, secondary, and because primary osteoporosis - age, postmenopausal). In order to assess the status of bone mineral density examination of patients underwent lumbar spine using two-photon X-ray densitometer. Found that in $75 \%$ of patients with chronic pancreatitis observed violations of bone mineralization.

Past studies substantiate the feasibility of sharing calcium-vitamin and mineral preparations and bisphosphonate rizendronic acid in the proposed scheme concomitant treatment of osteoporosis in patients with chronic pancreatitis. The expediency of using drugs Vitrum Kaltsium 600+D400 and Risendros in treatment of patients with chronic pancreatitis with concomitant osteodeficiency, leading to substantial significant improvement in bone mineral - growth of bone mineral density.

KEY WORDS: a chronic pancreatitis; the osteodeficiency; a mineral exchange; the mineral density of the bone tissue; Vitrum Calcium 600+D400, Risendros. 